Egyptian J. of Nutrition Vol. XXXIV No. 3 (2019)

\title{
The functional food properties of sour orange peel \\ (Citrusaurantium) and its effect on counteract obesity in rats
}

\author{
Samar, K.H.*; Seham A.M. Tharwat ${ }^{\star \star}$ and Ashraf \\ A.AbdelMegeid ${ }^{\star *}$ \\ * Graduate student, Nutrition and Food Science Department, Faculty \\ of Home Economics, Helwan University - Egypt \\ ${ }^{* *}$ Department of nutrition and food science, Faculty of home \\ economics, HelwanUniversityEgypt.
}

\section{Abstract}

The aim of this study was to determine the basic components of the Egyptian unripe and ripe sour orange peel, identification of its phenolic and flavonoids compounds and to study the effect of supplementation with two levels from dried unripe (DURSOP) or dried ripe sour orange peel (DRSOP) on feed intake (FI), body weight gain \% (BWG \%) in male albino rats (SpragoDawley strain), 25 days of age. A total of 36 rats weighting $(40 \pm 5 \mathrm{~g})$ were used. Rats were divided into two main groups, the first main group $(n=6)$ fed on basal diet (BD) and used as a negative control group (-ve). The second main group (30) rats fed on high fat diet all over the experimental period, and then rats were divided into five group as follows: one of them (6 rats) was fed on (HFD) and used as positive control group 


\section{Samar, K.H.; Seham A.M. Tharwat \\ and Ashraf A.AbdelMegeid}

(+ve). The other (four subgroups) were fed of (HFD) containing two levels (1.5 or $3 \%$ ) from (DURSOP or DRSOP). Analysis of the basic components of Egyptian sour orange unripe and ripe peels revealed that protein, fat, ash, fibers, moisture and vitamin $\mathrm{C}$ levels were $8.283 \%, 5.911 \%, 4.968 \%, 11.63 \%, 6.26 \%$ and $486.82 \mathrm{PPM}$ vs. $10.597 \%, 4.072 \%, 3.976 \%, 9.88 \%, 5.70 \%$ and 202.66 PPM, respectively), while the flavonoids compoundsextracted from (DURSOP or DRSOP) revealed the presence of 18 fraction, characterizes with high amount of Naringin, Hespirdin, apig6rhamnose 8-glucose, Rutin and Quercetrin to be the predominant compound, concerning phenolic compounds results revealed that (DURSOP and DRSOP) resulted in 19 fraction while (DRSOP) showed 21 fraction. The predominant phenolic in (DRSOP) was pyrogallol, which amounted in $9456.49 \mathrm{mg} / 100 \mathrm{gm}$ vs. 354.46 $\mathrm{mg} / 100 \mathrm{gm}$ in (DURSOP), results showed that the predominant phenolic in (DRSOP), Isoferulic , Benzoic, Ferulic, Catechein, $\mathrm{P}-\mathrm{OH}-$ benzoic, caffeine and 3.4,5- methoxy -cinamic. Biological results showed that the supplementation of (HFD) with (DURSOP or DRSOP) at levels (3 or $1.5 \%$ ), induced a significant reduction in body weight gain $\%$, organs weight / body weight $\%$ and peritoneal fat pad $\%$.In conclusion Egyptian sour orange peel considered as potential of natural source of polyphenols and flavonoids compounds that could be assist in management of obesity. 
Egyptian J. of Nutrition Vol. XXXIV No. 3 (2019)

\section{Introduction}

Obesity has become the main public health problem in recent decade, because it could increase the risk of chronic disease, such as type two diabetes and coronary heart disease (Haslam and Jemes, 2005). It is a complex metabolic disorders induced by imbalance between calories intake and metabolic expenditure, which expressed as an increase in a adipocyte number (hyperplasia) and size (hypertrophy) (Arner and Spalding, 2010).

Obesity therapies include reduction of nutrient absorption and administration of drugs that affect lipid mobilization and utilization. Owing to the adverse side effects associated with many anti-obesity drugs, more recent drug trials have focused on screening for natural sources that have been reported to reduce body weight and that generally have minimal side effects (Kishino et al., 2006).

Kang et al., (2012) reported that the peel of citrus SunkiHortextanake which widely used in traditional Asian medin for treatment of many disease, including indigestion and bronchial asthma. Moreover, it significantly decreased the accumulation of fatty droplets in liver tissue and had an anti-obesity effect via elevated B-oxidation and lipolysis in adipose tissue.

Therefore, the aim of this study was to determine the basic components of the Egyptian unripe and ripe sour orange peel and to study the effect of supplementation with two levels from (DURSOP) or (DRSOP) on some nutritional parameters in male albino rats. 


\section{Samar, K.H.; Seham A.M. Tharwat \\ and Ashraf A.AbdelMegeid}

\section{Materials and Methods}

\section{Materials:}

Sour orange (Citrus aurantium) were obtained from El-Oboor market. The raw orange ripe and unripe were washed carefully, and peel cut into small pieces to be exposed to solar energy at National Research Center and then ground to fine power.

\section{Chemical analysis:}

Moisture, protein, fat , ash and crudfiber content in sour orange peel (citrus aurantium), were determined according to the method outlined in A.O.A.C.(2007), vitamin C content determined according to (Rodriguez et al., 1992), flavonoids were determined according to the method of Price et al.,(1978), phenolic compounds were determined by HPLC method with UV detector at wavelength $280 \mathrm{~nm}$, according to Goupy et al., (1999), identification of individual phenolic compounds of samples were performed by HPLC method with UV detector at wavelength $330 \mathrm{~nm}$ according to (Crozier et al., 1997).

\section{Chemicals}

Vitamins, minerals, casein, cholinechloride and cellulose were purchased from El-Nasr pharm and chemi.Ind comp. Cairo, Egypt. 


\section{Egyptian J. of Nutrition Vol. XXXIV No. 3 (2019)}

\section{Rats}

Thirty-six male albino rats (SpraguDawely Strain) 25 days of age, weighing $(40 \pm 5 \mathrm{~g})$ were obtained from the laboratory of animal's colony, ministry of healthy and population. Helwan, Cairo, Egypt.

\section{Experimental animals design:}

Rats were housed in individual cages under hygienic laboratory condition and were feed on basal diet adlibitum for one week for adaptation in the animal house of faculty of home economics, HelwanUniversity. The basal diet (BD) in the preliminary experiment consists of $14 \%$ casein (Protein $>85 \%$ ), soy oil $(4 \%)$, cellulose $(5 \%)$, vitamin mixtures $(1 \%)$, Salt mixtures $(3.5 \%)$, choline chloride (0.25\%) and corn starch (72.25\%) Reeves et al., (1993). The salt mixture and vitamin mixture were prepared according to (Hegsted, 1941 and Campbell, 1963).

After a period of adaptation on $\mathrm{BD}$, rats were divided into two main groups. The first main group (6 rats) fed on $\mathrm{BD}$ and was considered (negative control group). The second main group: Thirty rats were fed on high fat diet (HFD) all over the experimental period containing (14\% protein from casein, $20 \%$ fat $19 \%$ saturated fat : $1 \%$ unsaturated fat" , $5 \%$ cellulose, $3.5 \%$ salt mixture, $1 \%$ vitamin mixture , $10 \%$ sucrose, $0.25 \%$ choline chloride and the remainder is corn starch. Supplementation of diet with dried unripe or ripe dried peel of sour orange was at the experience of starch. Rats of second main group were divided into five subgroups. One of them (6 rats) was fed on (HFD) used as a positive control group and the other four 


\section{Samar, K.H.; Seham A.M. Tharwat \\ and Ashraf A.AbdelMegeid}

groups were fed on HFD containing $1.5 \%$ dried unripe sour orange peel (DURSOP), 3\% (DURSOP), 1.5\% dried ripe sour orange peel (DRSOP) and 3\% (DRSOP), respectively. During the experimental period ( 8 weeks) body weight and food consumption were measured twice a week and total food intake of the experimental period was calculated, biological evaluation for different groups ,body weight gain \%, body weight\% were determined according to Chapman et al., (1959) .

Statistical analysis was carried out using SPSS statistical software version II (SAS., 2004)

\section{Results and discussion}

\section{Chemical composition of unripe and ripe sour orange peel:}

Results reveled that, the protein, fat, ash, fiber, moisture and vitamin C content were 8.283\%, 5.911\%, 4.968\%, 11.63\%,6.26\% and 486.82 PPMvs. 10.597\%,4.072\%, 3.976\%, 9.88\%, 5.70\% and 202.66 PPM, respectively. Our Results revealed that, unripe sour orange peel characterized with high amounts of vitamin C, fat, ash, fiber and moisture than ripe peel while ripe sour orange peel revealed a high content in protein than unripe (10.597 vs. 8.283 , respectively) our results are in a agreement with (Verpeut et al., 2013). 
Egyptian J. of Nutrition Vol. XXXIV No. 3 (2019)

Results revealed that vitamin $C$ in unripe and ripe sour orange peel was 486.82 vs. 202.66 PPM, respectively. Results revealed that unripe peel contained vitamin C 2.40 times more than those of ripe peels. Our results are in agreement with Diaz et al., (2009).

\section{Identification of flavonoids compounds of dried unripe and ripe sour orange peels}

Table (2) shows the identified flavonoid compounds extracted from unripe and ripe sour orange peels, which fractionated by using high performance liquid chromatography. Our results revealed that unripe and ripe sour orange peels contains 18 fractions. Unripe peel characterizes with high amounts of Naringin, Hespirdin, A pig-6 rhamnose, 8-glucose, rutin and quercetrin, in the amounts of $1774.18,1568.98,243.63,174.70$ and $155.61 \mathrm{mg} / 100 \mathrm{~g}$ of sample, while the compounds found in the amounts less than $100 \mathrm{mg} / 100 \mathrm{~g}$ of sample amounted in 88.32, 85.20, 15.82, 22.37, 18.62, 45.14, 48.51, 42.12, 29.10, 45.86, 14.54, 10.39 and $6.08 \mathrm{mg} / 100 \mathrm{~g}$ namely A pig-6 arbinose 8-glactose, A pig-7-o-neohespiroside, kamp. 3.7dirhomoside, Apigenin-7-glucose, Acacetin 7-neo.hesperside, Kaempferol 13-(2-p-camaroyl) glucose, Acacetin neo. hesperside, Quercetin, naringenin, Hespirtin , kampferol, Rhamnetin and Apegnin, respectively). Concerning ripe sour orange peel 18 flavonoids were fractionated from dried ripe peel, namelyhespirdin, naringin and Apig-6- rhamnose 8-glucose showed to be the predominant components which amounted in 1198.59, 400.00 and $237.49 \mathrm{mg} / 100 \mathrm{~g}$, respectively). 


\section{Samar, K.H.; Seham A.M. Tharwat \\ and Ashraf A.AbdelMegeid}

Apig.6-arbinose-8- glucose and rutin showed to be less than $100 \mathrm{mg} / 100 \mathrm{~g}$ sample, which amounted in $(92.85$ and $51.88 \mathrm{mg}$, respectively) while the major compounds less than $50 \mathrm{mg} / 100 \mathrm{~g}$ sample showed amounts $(26.49,8.25,26.96,4.93,13.11$, 27.37, 4.05, 17.39, 9.78, 9.74 and $1.36 \mathrm{mg} / 100 \mathrm{~g}$ sample for rutin, Apig-7-oneohespiroside, kamp-3.7-dirhomoside, quercetrin, A pigenin, 7glucose,Acecetin, 7-neo-hesperside, Acacetin neo-hesperside, quercetin, narngenin, hespirtin, kampferol, rhamentin and apegnin, respectively),from the above mentioned data it is clear that flavonoid contents in unripe sour orange peel was higher than ripe sour orange peel $(1774.18,1568.98,243.63$ and 174.70 vs. 400.00, 1198.59, 237,49 and 43.30, respectively) for naringin, hesperidin, Apig 6rhamnose, 8-glocse and rutin, respectively. Our results are in harmony with Nakajima et al., (2014).

In this concern Benaventaet al., 1997 also Sun et al., (2013) reported that among the flavonoids, citrus present considerable amounts of flavanones, flavones, flavonols and anthocyanins, the main flavonoids are flavanones. In this class of compounds, the most frequent ones are hesperidin andnaringin.

\section{Identification of phenolic compounds of dried unripe and ripe sour orange peel}

Table (3) shows the phenolic compounds of dried unripe (DURSOP) and ripe sour orange peel (DRSOP) resulted in 19 fractions, meanwhile (DURSOP) showed that the predominant 


\section{Egyptian J. of Nutrition Vol. XXXIV No. 3 (2019)}

phenolic were Pyrogallol, ISO-ferulic, Benzoic, Ferulic, Catechein, P-OH-benzoic, Caffeine and 3,4,5- Methoxy-cinamic which amounted in $(3541.46,435.39,213.49,174.39,143.70,104.27,103.22$ and $111.60 \mathrm{mg} / 100 \mathrm{~g}$ respectively).

On the other side results revealed that the ripe sour orange peel (DRSOP) showed that the predominant phenolics were Pyrogallol, ISO-ferulic ,Salycilic, P-OH-benzoic, Benzoic , Catechein , Ellagic , caffeine, ferulic, Protocatchuic, Catechol, which amounted in $(9456.49,239.41,120.44,84.62,80.89,68.72,61.75,58.45$, 49.49, 48.9 and $48.67 \mathrm{mg} / 100 \mathrm{~g}$ sample, respectively). Results revealed that other phenolic compounds include Coumarin and Alpha coumaric fractions amounted 24.81 and $5.90 \mathrm{mg} / 100 \mathrm{~g}$ sample found in (DRSOP). While disappeared in (DURSOP).

Our results revealed that the major phenolic content of the unripe and ripe (DSOP) was composed of pyrogallol(3541.46 vs $9456.49 \mathrm{mg} / 100 \mathrm{~g}$ ), Catechein (143.70 VS 68.72), P-OH-benzoic (104.27 VS 84.63), Caffeine (103.22 VS 58.45), vanillic (31.33 VS 18.14), while Chlorogenic , Catechol and Proticathuic recorded ( 21.23 vs. $20.42,21.18$ vs. 48.67 and 21.11 vs. 48.97 respectively). In this concern Kamran et al., (2009) reported that phenols and polyphenolic compounds, such as flavonoids have been shown to possess significant antioxidant activities.

Kang et al., (2012) suggested that the peel of citrus sunkihorthadanantiobesity effect via elevated B-oxidation and 


\section{Samar, K.H.; Seham A.M. Tharwat \\ and Ashraf A.AbdelMegeid}

lipolysis in adipose tissue. In this respect $\mathbf{L u}$ et al., (2013) reported that flavonoids are aromatic secondary plant metabolites that are important because of their nutraceuticalvalue, they show several bioactivities such as anti-adipogenic, antiviral antimicrobial and antiinflammatory activities.

Effect of supplementation with dried unripe or ripe sour orange peel on feed intake, body weight gain \% orangs weight / body weight and peritoneal fat pad $\%$ of 25 days of age albino rats:

Table (4) illustrate the effect of high fat diet (HFD) supplemented with dried unripe or ripe sour orange peel (DURSOP) or (RSOP) at levels (1.5 or3 \%) of feed intake (FI), body weight percent (BWG\%), results revealed that all groups 25 days age albino rats which fed on (HFD) for 8 weeks, no abnormal clinical signs were observed during the experimental period.Concerning $(\mathrm{FI})$ results revealed that there is no significant difference $(P<0.05)$ between the control negative group, positive control group and the treated groups which fed on (HFD) supplemented with (1.5 or $3 \%$ ) from (DURSOP) or (DRSOP).

Results revealed that $(\mathrm{FI})$ of albino rats 25 days of age (-ve) group fed on (BD) recorded non-significant difference, as compared with the (+ve) control group fed on (HFD). All groups fed on (HFD) supplemented with (1.5 or $3 \%$ ) from (DURSOP or DRSOP) recorded non-significant difference, as compared to the control (-ve) group fed on (BD) Concerning body weight gain\%, organs weight / body weight 


\section{Egyptian J. of Nutrition Vol. XXXIV No. 3 (2019)}

and peritoneal fat pad \%. Results presented in table (4) revealed the effect of (HFD) supplemented with 1.5 or $3 \%$ from (DURSOP or DRSOP) on body weight gain\%, organs weight / body weight and peritoneal fat pad \%, results revealed a significant increase in BWG $\%$, organs weight $/$ body weight $\%$ and peritoneal fat pad of control Positive group, as compared to the negative control group. However the caloric intake of negative group (-ve) fed on (BD) was lower, as compared to the positive group (+ve) fed on (HFD). Our results revealed that there is a significant decrease $(P<0.05)$ in (BWG\%, organs weight / body weight $\%$ and peritoneal fat pad \%) of all groups fed on (HFD) supplemented with 3 or $1.5 \%$ from (DURSOP or DRSOP), as compared to the (+ve) control group fed on (HFD).

Except of group feed on HFD supplemented with $1.5 \%$ of DURSOP for liver and kidney. we found that there was a nonsignificant difference between the effect of (DURSOP) and (DRSOP) at level $1.5 \%$ on suppressed body weight gain $\%$.

The best results of (DURSOP) or (DRSOP) as anti-obesity effect recorded by groups, which fed on (HFD), supplemented with dried (DURSOP or DRSOP) at 3\% followed by $1.5 \%$.

Our results agreed with the results found by Nakajima et al., (2014) who reported that citrus polyphenols could assist in the management of obesity, since they cause a reduction in a dipocytedifferentiation, lipid content in the cell and adipocyte apoptosis. 


\section{Samar, K.H.; Seham A.M. Tharwat \\ and Ashraf A.AbdelMegeid}

In conclusion, sour orange peel is an important source for bioactive flavonoids, may be a potential natural source for new antiobesity candidate.

Table (1). Major chemical composition of unripe and ripe sour orange peel are presented in

\begin{tabular}{c|c|c|c|c|c|c}
\hline \multirow{2}{*}{ Samples } & \multicolumn{5}{|c|}{ Chemical composition \% } & \multirow{2}{*}{$\begin{array}{c}\text { Vitamin C } \\
\text { source oranges }\end{array}$} \\
\cline { 2 - 6 } & Protein & Fat & Ash & Fibers & Moisture & PPM \\
\hline Unripe peels & 8.283 & 5.911 & 4.968 & 11.63 & 6.26 & 486.82 \\
\hline Ripe peels & 10.597 & 4.072 & 3.976 & 9.88 & 5.70 & 202.66 \\
\hline
\end{tabular}


Egyptian J. of Nutrition Vol. XXXIV No. 3 (2019)

Table (2): Identification of flavonoids Compounds of dried unripe and ripe sour orange peels:

\begin{tabular}{l|c|c}
\hline Flavonoids & $\begin{array}{c}\text { Snripe peels } \\
\mathrm{mg} / 100 \mathrm{gm}\end{array}$ & $\begin{array}{c}\text { Ripe peels } \\
\mathrm{mg} / 100 \mathrm{gm}\end{array}$ \\
\hline Apig.6-arbinose 8-glactose & 88.32 & 92.85 \\
\hline Apig.6-rhamnose 8-glucose & 243.63 & 237.49 \\
\hline Naringin & 1774.18 & 400.00 \\
\hline Hesperidin & 1568.98 & 1198.59 \\
\hline Rutin & 174.70 & 43.30 \\
\hline Apig.7-0-neohespiroside & 85.20 & 26.49 \\
\hline Kamp.3.7-dirhamoside & 15.82 & 8.25 \\
\hline Quercetrin & 155.61 & 26.96 \\
\hline Apigenin-7-glucose & 22.37 & 4.93 \\
\hline Acecetin-7-neo hesperside & 18.62 & 13.11 \\
\hline Kaempferol13-(2-p- & 45.14 & 51.88 \\
comaroyl)glucose & 48.51 & 27.37 \\
\hline Acacetin neo. rusperside & 42.12 & 4.05 \\
\hline Quercetin & 29.10 & 17.39 \\
\hline Narngenin & 45.86 & 39.96 \\
\hline Hespirtin & 14.54 & 9.78 \\
\hline Kampferol & 10.39 & 9.74 \\
\hline Rhamentin & 6.08 & 1.36 \\
\hline Apegnin & & \\
\hline
\end{tabular}




\section{Samar, K.H.; Seham A.M. Tharwat}

\section{and Ashraf A.AbdelMegeid}

Table (3): Identification of phenolic compounds of dried unripe and ripe sour orange peel:

\begin{tabular}{|c|c|c|}
\hline Samples & \multicolumn{2}{|c|}{$\mathrm{Mg} / 100 \mathrm{gm}$ of sample } \\
\hline compounds( PPM) & Unripe peels & Ripe peels \\
\hline Gallic & 5.70 & 6.27 \\
\hline Pyrogallol & 3541.46 & 9456.49 \\
\hline 4-amino-benolic & 1.26 & 3.88 \\
\hline Protochatchuic & 1.26 & 3.88 \\
\hline Proticathuic & 21.11 & 48.97 \\
\hline Catechein & 143.70 & 68.72 \\
\hline Chlorogenic & 21.23 & 20.42 \\
\hline Catechol & 21.18 & 48.67 \\
\hline Caffeine & 103.22 & 58.45 \\
\hline P-OH-benzoic & 104.27 & 84.62 \\
\hline Caffeic & 3.57 & 13.29 \\
\hline Vanillic & 31.363 & 18.14 \\
\hline P-coumaric & 16.93 & 19.48 \\
\hline Ferulic & 174.39 & 49.49 \\
\hline Iso-ferulic & 435.39 & 239.41 \\
\hline Alpha-Coumaric & - & 5.90 \\
\hline Ellagic & 73.14 & 61.75 \\
\hline Benzoic & 213.49 & 80.89 \\
\hline Coumarin & - & 24.81 \\
\hline 3,4,5 methoxy-cinamic & 111.60 & 22.59 \\
\hline Salycilic & 60.22 & 120.44 \\
\hline Cinnamic & 12.54 & 10.47 \\
\hline
\end{tabular}


Egyptian J. of Nutrition Vol. XXXIV No. 3 (2019)

Table (4): Effect of supplementation with dried unripe or ripe sour orange peel on feed intake, body weight gain \% orangs weight / body weight and peritoneal fat pad $\%$ of 25 days of age albino rats:

\begin{tabular}{|c|c|c|c|c|c|c|}
\hline \multirow{2}{*}{\multicolumn{2}{|c|}{ parameter }} & \multirow{2}{*}{$\begin{array}{c}\text { Feed intake } \\
\text { (g/day } \\
\text { /each rat) }\end{array}$} & \multirow{2}{*}{$\begin{array}{c}\text { Body } \\
\text { weight } \\
\text { gain \% }\end{array}$} & \multicolumn{2}{|c|}{$\begin{array}{l}\text { Organs weight / } \\
\text { body weight \% }\end{array}$} & \multirow{2}{*}{$\begin{array}{l}\text { Peritoneal } \\
\text { fat pad \% }\end{array}$} \\
\hline & & & & Liver & Kidney & \\
\hline \multirow{2}{*}{\multicolumn{2}{|c|}{ Control (-ve) group }} & $13.051^{\mathrm{a}}$ & $228.670^{d}$ & $2.641^{\mathrm{e}}$ & $0.503^{e}$ & $2.978^{e}$ \\
\hline & & \pm 4.90 & \pm 4.886 & \pm 0.102 & \pm 0.056 & \pm 0.149 \\
\hline \multirow{2}{*}{\multicolumn{2}{|c|}{$\begin{array}{l}\text { Control (+ve) group } \\
\text { fedon (HFD) }\end{array}$}} & $13.113^{a}$ & $400.543^{a}$ & $4.038^{a}$ & $0.888^{a}$ & $4.436^{a}$ \\
\hline & & \pm 0.448 & \pm 8.630 & \pm 0.347 & \pm 0.062 & \pm 0.088 \\
\hline \multirow{5}{*}{ 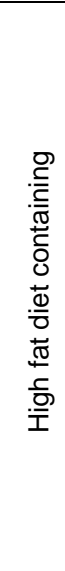 } & $\begin{array}{l}1.5 \% \text { dried } \\
\text { un ripe peel } \\
\text { (DURSP) }\end{array}$ & $\begin{array}{l}12.916^{a} \\
\pm 0.735\end{array}$ & $\begin{array}{r}356.713^{b} \\
\pm 16.145\end{array}$ & $\begin{array}{l}3.781^{\mathrm{ab}} \\
\pm 0.333\end{array}$ & $\begin{array}{l}0.771^{\mathrm{b}} \\
\pm 0.054\end{array}$ & $\begin{array}{l}3.910^{c} \\
\pm 0.080\end{array}$ \\
\hline & $\begin{array}{c}\text { 3\%dried un } \\
\text { ripe peel } \\
\text { (DURSOP) }\end{array}$ & $\begin{array}{l}13.166^{a} \\
\pm 0.408\end{array}$ & $\begin{array}{l}302.413^{c} \\
\pm 17.633\end{array}$ & $\begin{array}{l}3.476^{c} \\
\pm 0.208\end{array}$ & $\begin{array}{l}0.650^{c} \\
\pm 0.062\end{array}$ & $\begin{array}{l}3.456^{d} \\
\pm 0.080\end{array}$ \\
\hline & $\begin{array}{c}1.5 \% \text { dried } \\
\text { rip peel } \\
(\mathrm{DRP})\end{array}$ & $\begin{array}{l}13.333^{a} \\
\pm 0.408\end{array}$ & $\begin{array}{l}368.324^{b} \\
\pm 25.139\end{array}$ & $\begin{array}{l}3.528^{\mathrm{bc}} \\
\pm 0.178\end{array}$ & $\begin{array}{l}0.700^{c} \\
\pm 0.031\end{array}$ & $\begin{array}{l}4.053^{b} \\
\pm 0.097\end{array}$ \\
\hline & $3 \%$ dried & $13.583^{a}$ & $318.250^{c}$ & $3.015^{d}$ & $0.571^{d}$ & $3.573^{d}$ \\
\hline & (DRSOP) & \pm 0.736 & \pm 17.943 & \pm 0.132 & \pm 0.050 & \pm 0.107 \\
\hline
\end{tabular}

Values are expressed as means \pm SD.

Values at the same column with different letters are significant at $\mathrm{P}<0.05$ 


\section{Samar, K.H.; Seham A.M. Tharwat \\ and Ashraf A.AbdelMegeid}

\section{References}

A.O.A.C. (Association of official Analytical chemists) (2007).

"Official methods of analysis of the association of official analytical chemists", $15^{\text {th }}$ edition, Association of official analytical chemists, Inc., Arrington. Virginia, USA.

Arner, P. and Spalding, K.L. (2010).

"Fatcellturns over in humans. Biochemical and Biophysical research communications; 396:101-104.

Benaventa, G.O.; Castillo, J. M. and Marin, F.R. (1997).

uses and properties of citrus flavonoids jofargic and food chem.; 45(15)4505-4515.

Campbell, J. A. (1963).

Methodology of protein vealuation, RGA nutria. Document R, 101 adds, 37, June meeting new york.

Chapman, D.G.; Gasilla, R. and Cambef, J .A. (1959).

Evaluation of protein in food, L./A method for the determination of protein efficiency rationcan J. Biochem Physiol., 37:679-686.

Crozier, A.; Jensen, E.; Lean, M.E.J. and McDonald.M.S. (1997).

Quantitative analysis of flavonoids by reverse phase highperformance liquid chromatography. $J$ Chromatogr A 761: 315-321. 
Egyptian J. of Nutrition Vol. XXXIV No. 3 (2019)

Diaz,A .B.; Deory,I.; Carol,L. and Blandino,A. (2009).

Production of hydrolytic enzymes from grapepomace and orange peels. Chemical Engineering Transctions , 17 : $1143-$ 1148.

Goupy, P.; Hugues, M.; Boivin, P. and Amiot, M.J. (1999).

Antioxidant compounds of barley (Hordeumvulgare) and malt extracts. Journal of the Science of Food and Agriculture, 79: 1625-1634.

Haslam, D.W. and James, W.P.S. (2005).

"obesity Lancet; 366; 1197-1209.

Hegsted, M.; Mill,R. S., Elvjjem, G.A. and Hart, E.B. (1941).

Cholin in the nutrition of chicks. J. Biochem., 138-459.

Kamran,G.; Ghasemi,Y. and Zadeh,A. M. (2009).

Antioxodantactivity, Phenol and flavonoid contents of 13 citrus species peels and tissues. J. pharm . Sci., 22 (3): 277 281.

Kang, II.; Shin, S.H., Kim, M.H.;Yoan, A. S. and Kim, J. S. (2012).

Immature citrus sunki peel ex tract exhibibitantiobesity by Boxidation boil. Pharm. Bull., 35(2): 223-230.

Kishino, E.; Ito, M.T.; Fujita, K. and Kuchi, Y. (2006).

Amixture of the salacia reticulate aqueous extract and cyclodextrin reduced the accumulation of visceral fat mass in mice and rats with high -fardiet induce obesity. J. Nutr; 135: 433-439 
Samar, K.H.; Seham A.M. Tharwat

and Ashraf A.AbdelMegeid

Lu,Y.; Xi. W.; Ding,X. and Zhang,Y. (2013).

Citrange fruit Extracts allevivate obesity. $\mathrm{J}$ of clinical Bioch and Nutr ., $43: 201-209$.

Nakajima , M.V.; Macedo, A.G. and Macedo, A.J . (2014).

Citrus bioactive phenolics.Food science and technology; 59: 1205-1212.

Price, M.L.; Van-Scouo, C.S. and Buttet, L.G. (1978).

A critical evaluation of the vanillin reaction as an assay for tannins sorghum green. J. Agric Food Chem., 26: 5.

Reeves, P.G.; Bilson, F.H and Fahmy, Q. (1993).

Reported of the American institute of nutrition adholwriloing committee on the formulation of the Ain-76.A-Rodent diet. J. Nutri., 132:1939-1951

Rodriguez - Rodriguez, C.; Torres, N.; Gutierrez- Uribe, J.A.; Noriega, L.G. and Torre- Villavazo. (1992).

The effect of isorhamnetic glycosides extracted from opuntiaficusindica in a mouse model of deit induced obesity" Food Funct, 6:805-815.

SAS, (2004).

Statistical analysis system, SAS users guide, statistics. SAS institute INC. Editors, Cart. And NC.

Sun, Y.; Q Jao, L.; Shen, Y.; and Ye.X. (2013).

Polypenol profile and antioxidant activity of physiological drop of citrus fruits.Journal of food science, 78(1)37-42.

Verpeut,J. L.; Walters,A. L. and Bello, N. T. (2013).

Citrus aurantiumand Rhodiolarosa in Combination reduce visceral white adipose tissue and increase hypothalamic norepinephrince in a rat model of diet induced obesity . Nutrition Research ., 33 (6) : $503-512$. 
Egyptian J. of Nutrition Vol. XXXIV No. 3 (2019)

الخصائص الوظيفية لقشور موالح البرتقال الحامضي وتأثيره على مقاومة السمنة في الفئران

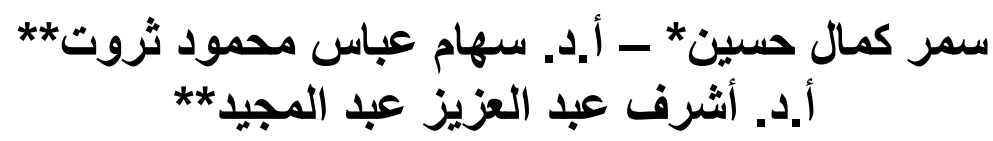

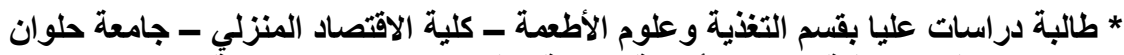

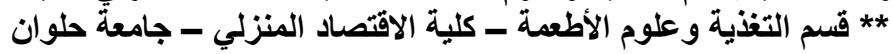

\section{الملخص العربي}

الهدف من هذه الدراسة هو تقدير المكونات الأساسية الموجودة في قثور البرتقال المصريالحامضي الغير تام النضج والتام النضج وتقدير المركبات الفينولية والفلافونات وكذللك

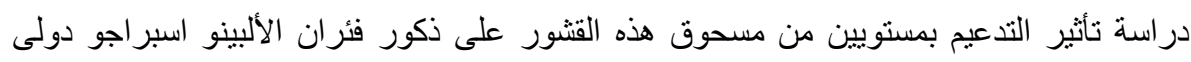

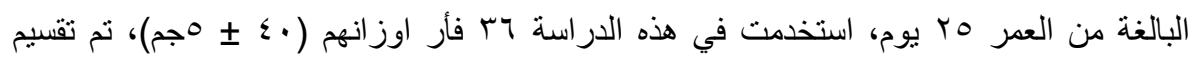
الفئران الي مجموعتين رئيسيتين، المجموعة الرئيسية الأولي (عددها ج 7 فئران) نم تغذيتها علي غذاء أساسي واستخدمت كمجموعة ضابطة سالبة. المجموعة الرئيسية الثانية (عددها .ب فأر) تم تغذيتها علي غذاء عالي الدهن طوال فترة التجربة، نم تقسيمهم الي خمس مجموعات كالتالي: مجموعة منهم (عددها 7 فئران) تم تغذيتها علي غذاء عالي الدهن ونم استخدامها كمجموعة ضابطة موجبة. المجموعات الباقية (ع مجموعات فرعية) تم تغذيتها على غذاء عالي الدهن ومحتوية علي مستويين (1, أو ب٪\%) قشور برتقال غير تام النضج أو قثور برتقال تام النضح. أثارت نتائج تحليل المكونات الأساسية لقثور البرتقال المصري غير تام النضج والناضج أن

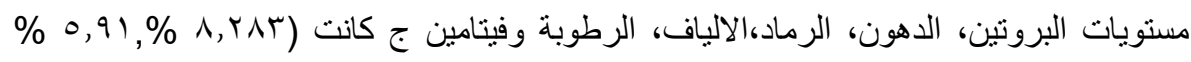

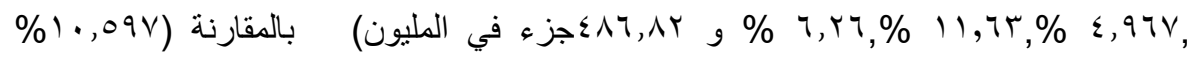

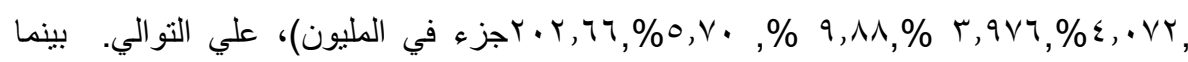
وجد أن محتوى المركبات الفلافونية المستخلصة من قشور البرتقال الغير ناضح وتام النضج اشارت الي وجود 11 مركب.تميزت القشور الغير ناضجة بارتفاع محتواها

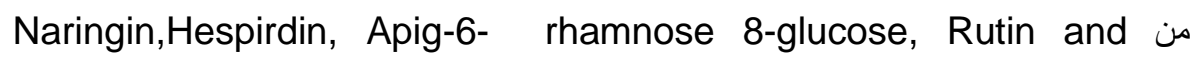
Quercetrin 


\section{Samar, K.H.; Seham A.M. Tharwat}

\section{and Ashraf A.AbdelMegeid}

وعدد اب مركب من القشور الناضجة وقد كان المركب الرئيسي السائد من الفينولات هو

Pyrogallol

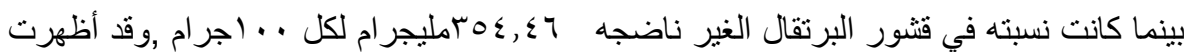
Isoferulic , النتائج أن المركبات الفينولية السائدة في قشور البرتقال الحامضي تام النضج هي Benzoic , Ferulic, Catechein, P-OH-benzoic, caffeine and 3.4,5methoxy -cinamic وقد أظهرت النتائج البيولوجية ان الغذاء عالي الدهن المدعم بمستويين (r\% أو 0, 1 \% من قشور البرتقال الحامضي التام النضج والغير تام النضج أدى الىى حدوث خفض معنويفي النسبة المئوية للزيادة في الوزن، النسبة المئوية لأوزانأعضاء الفئران، ونسبة الدهون في الغشاء البروتوني. وخلصت النتائج الي ان الفينولات العديدة و الفلافونات الموجودة في قثور البرتقال الحامضي الغير ناضج و الناضج يمكن أن تساعد في مكافحة السمنة. 